\title{
Evaluation of Factors Affecting Outcome in Growth Hormone-Secreting Pituitary Adenomas
}

\author{
Amit Padwal ${ }^{1}$ Jagath Lal Gangadharan ${ }^{1}$ Dwarakanath Srinivas ${ }^{1}$ Sampath Somanna ${ }^{1}$ \\ ${ }^{1}$ Department of Neurosurgery, National Institute of Mental Health \\ and Neuro Sciences, Bengaluru, India \\ Address for correspondence Dwarakanath Srinivas, MBBS, MS, MCH, \\ Faculty Block, Neurocenter, National Institute of Mental Health \\ and Neuro Sciences, Bengaluru 560029, Karnataka, India \\ Indian J Neurosurg 2017;6:176-183. \\ (e-mail: dwarakaneuro@yahoo.com).
}

\begin{abstract}
Introduction Management of functioning pituitary adenomas is challenging as they can present with features of an intracranial mass, systemic effects, or a combination of both. In this series, one of the largest in available literature from our country, we have analyzed our experience with surgical management of growth hormone (GH)secreting pituitary adenomas and factors influencing their hormonal remission.

Materials and Methods The data of all functional pituitary adenomas operated at our institute from January 2002 to December 2011 were obtained from the case files of these patients. This was studied for various clinical-radiologic features, management stratagems, and clinical and hormonal outcomes.

Results Ninety-three patients of GH-secreting pituitary adenomas with a mean age of 32.7 years were included in the study. Fifty-three $(57 \%)$ patients had headache at presentation; $46(49 \%)$ had visual complaints, whereas menstrual irregularity was

\section{Keywords}

- pituitary adenomas

- invasive adenoma

- growth hormonesecreting adenomas

- acromegaly seen in majority of females. Mean GH level was $52.05 \mathrm{ng} / \mathrm{mL}$. Fifty (53\%) patients had invasive adenoma; 32 had cavernous sinus extension. Among 80 patients with hormonal follow-up, 43 (53.75\%) achieved remission of $\mathrm{GH}$ level $<5 \mathrm{ng} / \mathrm{mL}$.

Conclusion In this series, one of the largest of its kind, the main factors influencing unfavorable outcome include macroadenomas, invasiveness, high basal $\mathrm{GH}>45 \mathrm{ng} /$ $\mathrm{mL}$ levels, and mixed adenomas.
\end{abstract}

\section{Introduction}

Functioning or hormonally active pituitary adenomas present a special challenge as they can present either with features of an intracranial mass, endocrinologic features, or both. Predicting outcome in these tumors is of extreme clinical importance in guiding the intensity of clinical, radiologic, and hormonal follow-up and the need for adjuvant therapy after surgical resection. At present three therapeutic options are available: neurosurgery, radiotherapy/ radiosurgery, and pharmacotherapy, whose relative role is, though still subject of active debate, complementary. In this series, one of the largest in available literature from our country, we analyze our experience with surgical management of growth hormone (GH)-secreting pituitary adenomas and also review the available literature.

\section{Materials and Methods}

This retrospective analysis was conducted on cases of functional pituitary adenomas operated at our institute from January 2002 to December 2011. The data of all operated pituitary adenomas were obtained from the case files of these patients, which were collected from medical records received

July 21, 2016

accepted

October 18, 2016

published online

September 22, 2017
DOI https://doi.org/

10.1055/s-0037-1598091. ISSN 2277-954X.
(C) 2017 Neurological Surgeons' Society of India
License terms

(®) $\ominus \circledast$ 
department. This was studied for various clinical-radiologic features, management stratagems, and clinical and hormonal outcomes. The cases of residual/recurrent pituitary adenomas operated elsewhere $(n=6)$ and referred to us for gamma knife radiosurgery or reexplorations were also included, but these cases were not considered for calculating remission and recurrence rates as none of these patients had enough followup and postoperative hormonal evaluation. Patients with functional adenoma who were on medical management and did not undergo any surgical intervention at our institute were also excluded from the study.

\section{Diagnostic Criteria}

Acromegaly was diagnosed on the basis of typical clinical features and elevated fasting plasma GH levels and not suppressible to less than $2 \mathrm{ng} / \mathrm{mL}$ during an oral glucose tolerance testing (OGTT) with $75 \mathrm{~g}$ glucose. We did not include plasma insulin-like growth factor 1 (IGF-1) levels as many of our patients could not afford the cost of the test.

\section{Radiologic Features}

Tumors were classified into macroadenomas $(>10 \mathrm{~mm}$ ) or microadenomas $(<10 \mathrm{~mm}$ ) on the basis of magnetic resonance imaging (MRI). They were further classified as per WilsonHardy classification to define stage and grade of adenoma. The evidence of carotid encasement in MRI scan defined invasion of cavernous sinus.

\section{Remission Criteria}

Biochemical remission was defined as postoperative serum $\mathrm{GH}$ value $<5 \mathrm{ng} / \mathrm{mL}$ in immediate postoperative period (within 72 hours) as well as on follow-up.

\section{Statistical Analysis}

Statistical analysis was done using SPSS 15 (SPSS Inc., Chicago, Illinois, United States). Descriptive statistics were given for continuous variables with mean and standard deviation.
Categorical variables were given with frequency and percentage. Association between two variables was tested using chi-square test.

\section{Results}

There were a total of 645 patients with pituitary adenomas who were operated at our institute from January 2002 to December $2011 ; 122$ (19\%) of them were functional pituitary adenomas. Among them, 93 (14\%) were GH-secreting pituitary adenomas, 14 (2\%) were prolactinomas, and remaining $15(2 \%)$ were adrenocorticotropic hormone $(\mathrm{ACTH})$-secreting pituitary adenomas.

Demography: Among 93 patients, 51 patients were males and 42 were females. Their age ranged from 13 to 60 years. About $77 \%$ of the patients were younger than 40 years. The mean age was $32.71 \pm 10.16$ years.

Clinical presentation: All patients presented with endocrinologic manifestations. In females, the most common endocrinologic manifestation was menstrual disturbance. Forty-six (49\%) patients presented with visual complaints, and most common visual problem identified was bitemporal hemianopia in 34 (73\%) patients. Uncommon presentations included pituitary apoplexy in four patients and trigeminal nerve involvement due to cavernous sinus invasion. Details are given in - Fig. 1.

Hormonal evaluation: The mean GH level was $52.05 \mathrm{ng} / \mathrm{mL}$ (range: 6-701 ng/mL). About half the patients had serum $\mathrm{GH}$ values $\geq 40 \mathrm{ng} / \mathrm{mL}$. Associated hypothyroidism was present in 13 patients and hyperthyroidism in 6. Hyperprolactinemia was observed in 26 (28\%) patients. Six patients had serum prolactin value $>200 \mathrm{ng} / \mathrm{mL}$. One patient had value between 100 and $200 \mathrm{ng} / \mathrm{mL}$ whereas the remaining 19 patients had value $100 \mathrm{ng} / \mathrm{mL}$ probably due to a stalk effect.

Radiology: Patients were divided into Wilson-Hardy grade based on MRI findings (-Table 1). Only one patient had a microadenoma whereas the rest had macroadenomas. Among

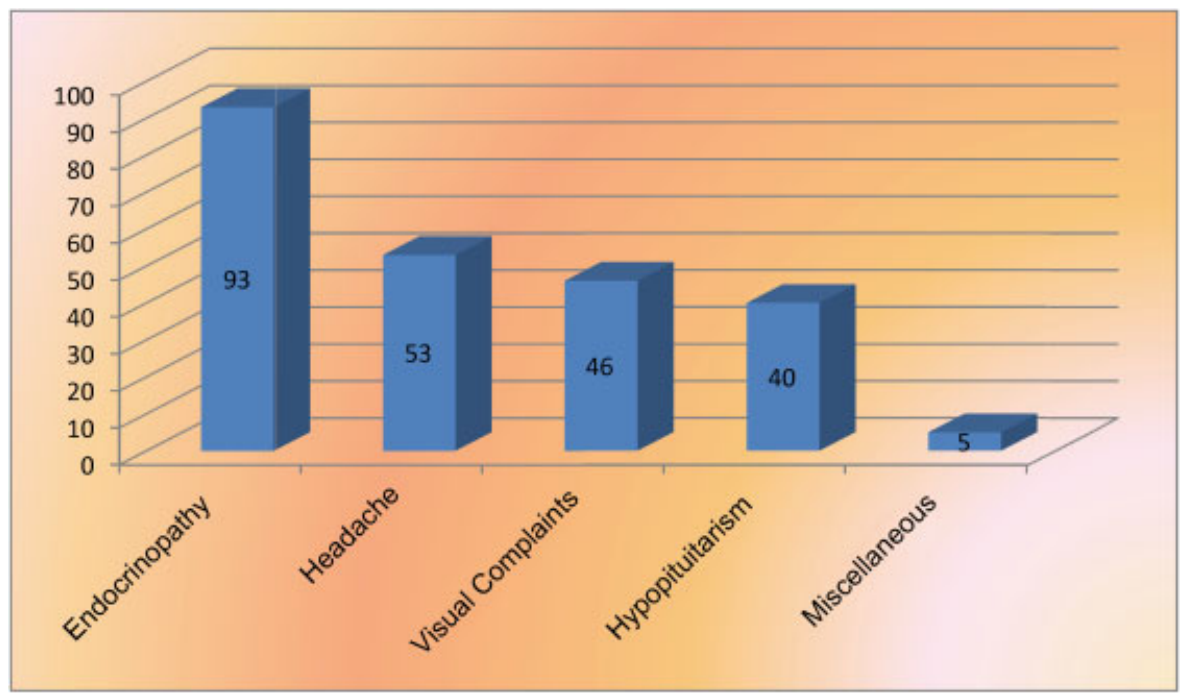

Fig. 1 Clinical features at presentation. 
Table 1 Wilson-Hardy grading of GH-secreting pituitary adenomas

\begin{tabular}{|c|c|c|c|}
\hline \multicolumn{2}{|c|}{ Wilson-Hardy grade } & \multirow{2}{*}{$\frac{\text { No. of patients }}{1}$} & \multirow{2}{*}{$\begin{array}{l}\frac{\%}{1.1} \\
\end{array}$} \\
\hline$I(n=1)$ & & & \\
\hline \multirow[t]{6}{*}{ II $(n=55)$} & 0 & 8 & 8.6 \\
\hline & $\bar{A}$ & 7 & 7.5 \\
\hline & $B$ & 23 & 24.7 \\
\hline & C & 4 & 4.3 \\
\hline & $\mathrm{D}$ & 4 & 4.3 \\
\hline & $\bar{E}$ & 9 & 9.7 \\
\hline \multirow[t]{5}{*}{ III $(n=13)$} & 0 & 1 & 1.1 \\
\hline & B & 4 & 4.3 \\
\hline & C & 1 & 1.1 \\
\hline & $\mathrm{D}$ & 1 & 1.1 \\
\hline & $\bar{E}$ & 6 & 6.5 \\
\hline \multirow[t]{4}{*}{ IV $(n=24)$} & $B$ & 2 & 2.2 \\
\hline & C & 3 & 3.2 \\
\hline & $\mathrm{D}$ & 2 & 2.2 \\
\hline & $\bar{E}$ & 17 & 18.3 \\
\hline Total & & 93 & 100.0 \\
\hline
\end{tabular}

Abbreviation: $\mathrm{GH}$, growth hormone.

93 patients, 50 (53\%) had invasive adenoma whereas remaining 43 had noninvasive adenoma (-Fig. 2). Among the patients with invasive adenoma, 32 (34\%) had adenomas invading the cavernous sinus.

Management: Two patients received preoperative medical management elsewhere. One patient had received somatostatin analogue and other received dopamine agonist. All 93 patients underwent surgery, with the endonasal transsphenoidal route used in 87 patients (-Figs. 3, 4).

Outcome and complications: Of 93 patients, 18 (19\%) patients had postoperative cerebrospinal fluid (CSF) leaks. All

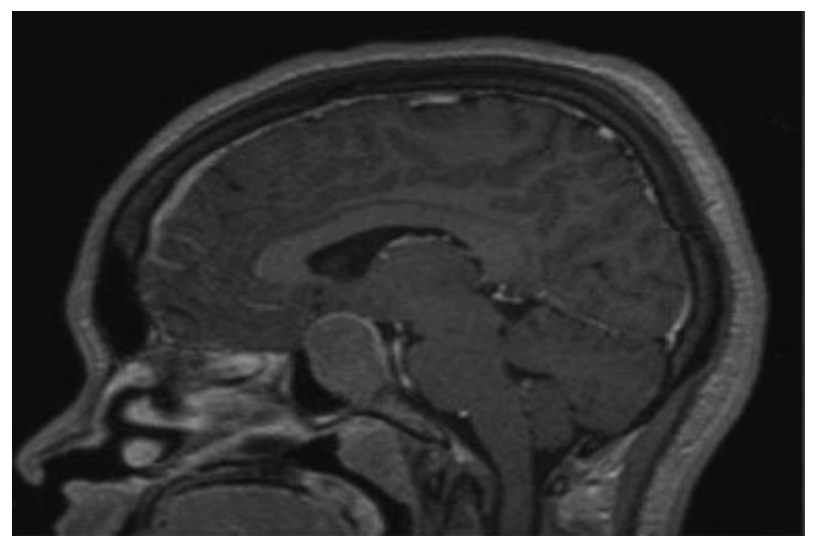

Fig. 2 Preoperative magnetic resonance imaging (MRI) T1 sagittal with gadolinium contrast showing $\mathrm{GH}$-secreting pituitary adenoma stage IIB.
CSF leaks were initially managed with lumbar drain placement. Four patients required reexploration and sellar floor reconstruction. Among these 18 patients, 8 had meningitis, which was managed with appropriate antibiotics. None of the patients without CSF leak developed meningitis; thus CSF leak was a significant risk factor for postoperative meningitis $(p<0.05)$. Fifteen (16\%) patients had postoperative diabetes insipidus, of whom only three patients needed longterm hormonal supplementation. One patient had intraoperative internal carotid artery (ICA) injury for which she underwent craniotomy and trap ligation of ICA. Rest of her postoperative period was uneventful and she was discharged without any fresh focal neurologic deficit. Two patients had

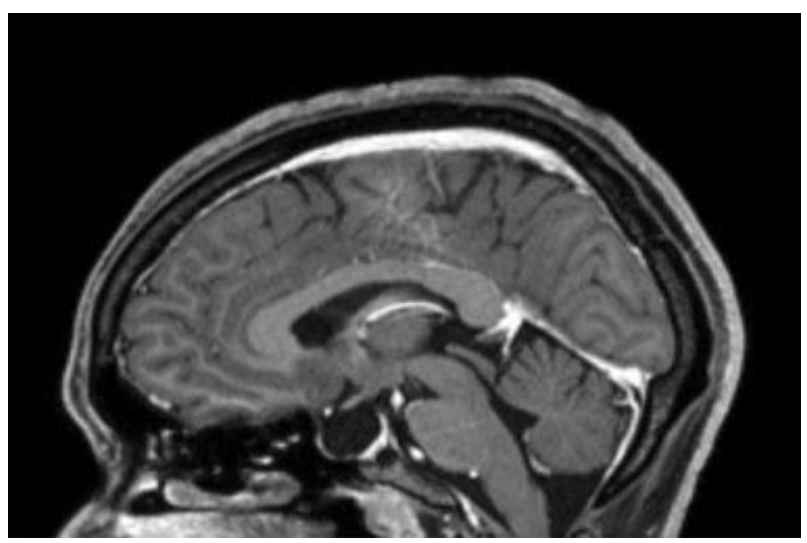

Fig. 3 Postoperative MRI T1 sagittal with gadolinium contrast at follow-up showing complete decompression. 


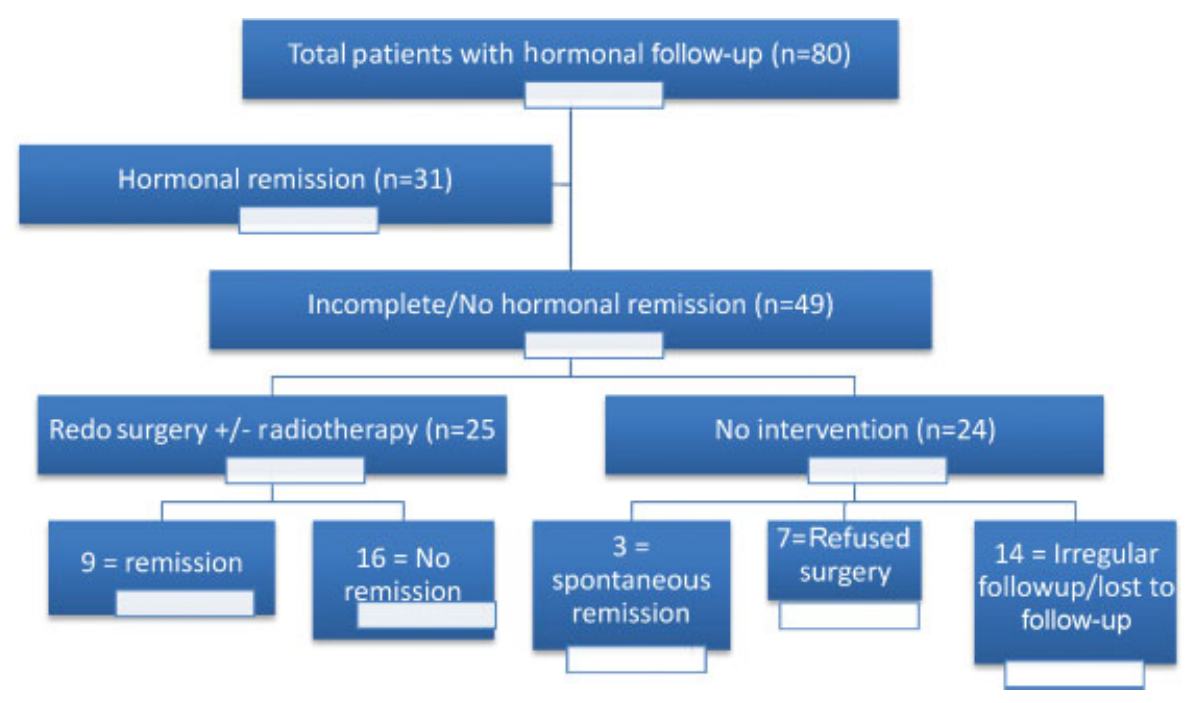

Fig. 4 Management of patients: flowchart.

intraoperative cavernous sinus injury (probably due a lateral trajectory) and they developed postoperative hemiparesis. Visual deterioration was observed in two patients. Two patients expired postoperatively: one due to sudden cardiac arrest whereas the second expired due to meningitis.

Follow-up: The follow-up period ranged from 6 weeks to 7 years with the mean follow-up being 15.07 months.

Clinical: The patients, who had achieved endocrinologic remission, had subjective improvement in their endocrinologic manifestations.

- Hormonal: Eighty patients had hormonal follow-up, of whom 31 patients had postoperative $\mathrm{GH}$ value $<5 \mathrm{ng} / \mathrm{mL}$, thus achieving immediate postoperative remission. Of the remaining 49 patients, 25 underwent reintervention in an attempt to achieve remission. Among these 25 patients, 9 (36\%) achieved remission following second intervention. The details are given in -Table 2. Among the remaining patients, 16 had hormonal follow-up. Three (12\%) patients had serum GH levels $<10 \mathrm{ng} / \mathrm{mL}$, one (4\%) had GH level 10 to $20 \mathrm{ng} / \mathrm{mL}$, whereas 12 had values $>20$ $\mathrm{ng} / \mathrm{mL}$.

- There were 21 patients who did not achieve remission and did not undergo second intervention were analyzed. Among these, seven (33\%) had serum GH levels $<10 \mathrm{ng}$ / $\mathrm{mL}$. As these patients improved symptomatically, they refused second intervention. Eight (38\%) patients had serum GH level 10 to $20 \mathrm{ng} / \mathrm{mL}$ whereas the remaining six (29\%) had serum GH level $>20 \mathrm{ng} / \mathrm{mL}$. Three patients who did not undergo any reintervention achieved remission spontaneously during follow-up. Thus among 80 patients, 43 (53.75\%) achieved biochemical remission. Ten (12.5\%) patients achieved almost complete biochemical remission. This coupled with their significant clinical improvement made them refuse a second surgery (-Fig. 4).

- Radiologic: Among 93 patients, 52 (56\%) patients had follow-up MRI. Among 42 patients who achieved remission, 35 had follow-up MRI and 4 had only followup computed tomographic (CT) imaging. Among these

Table 2 Correlation between cavernous sinus invasion and remission

\begin{tabular}{|c|c|c|c|c|}
\hline \multirow[t]{2}{*}{ Cavernous sinus invasion } & \multirow[t]{2}{*}{ Total no. of patients } & \multicolumn{2}{|c|}{ Final remission } & \multirow[t]{2}{*}{ Total } \\
\hline & & Yes & No & \\
\hline \multirow[t]{3}{*}{ No } & Total no. & 32 & 22 & 54 \\
\hline & $\%$ without invasion & $59.3 \%$ & $40.7 \%$ & $100.0 \%$ \\
\hline & $\%$ within final remission & $76.2 \%$ & $57.9 \%$ & $67.5 \%$ \\
\hline \multirow[t]{3}{*}{ Yes } & Total no. & 10 & 16 & 26 \\
\hline & $\%$ with invasion & $38.5 \%$ & $61.5 \%$ & $100.0 \%$ \\
\hline & $\%$ within final remission & $23.8 \%$ & $42.1 \%$ & $32.5 \%$ \\
\hline \multirow[t]{3}{*}{ Total } & & 42 & 38 & 80 \\
\hline & & $52.5 \%$ & $47.5 \%$ & $100.0 \%$ \\
\hline & & $100.0 \%$ & $100.0 \%$ & $100.0 \%$ \\
\hline
\end{tabular}


Table 3 Correlation between grade of the tumor and remission

\begin{tabular}{|c|c|c|c|c|}
\hline \multirow[t]{2}{*}{ Hardy grade } & \multirow[t]{2}{*}{ No. of patients } & \multicolumn{2}{|c|}{ Final remission } & \multirow[t]{2}{*}{ Total } \\
\hline & & Yes & No & \\
\hline \multirow[t]{3}{*}{0} & Total no. & 7 & 0 & 7 \\
\hline & \% within Hardy grade & $100.0 \%$ & $0.0 \%$ & $100.0 \%$ \\
\hline & $\%$ within final remission & $16.7 \%$ & $0.0 \%$ & $8.8 \%$ \\
\hline \multirow[t]{3}{*}{$A$} & Total no. & 4 & 3 & 7 \\
\hline & $\%$ within Hardy grade & $57.1 \%$ & $42.9 \%$ & $100.0 \%$ \\
\hline & $\%$ within final remission & $9.5 \%$ & $7.9 \%$ & $8.8 \%$ \\
\hline \multirow[t]{3}{*}{$B$} & Total no. & 15 & 11 & 26 \\
\hline & \% within Hardy grade & $57.7 \%$ & $42.3 \%$ & $100.0 \%$ \\
\hline & \% within final remission & $35.7 \%$ & $28.9 \%$ & $32.5 \%$ \\
\hline \multirow[t]{3}{*}{$\mathrm{C}$} & Total no. & 3 & 4 & 7 \\
\hline & $\%$ within Hardy grade & $42.9 \%$ & $57.1 \%$ & $100.0 \%$ \\
\hline & $\%$ within final remission & $7.1 \%$ & $10.5 \%$ & $8.8 \%$ \\
\hline \multirow[t]{3}{*}{$\mathrm{D}$} & Total no. & 3 & 4 & 7 \\
\hline & \% within Hardy grade & $42.9 \%$ & $57.1 \%$ & $100.0 \%$ \\
\hline & \% within final remission & $7.1 \%$ & $10.5 \%$ & $8.8 \%$ \\
\hline \multirow[t]{3}{*}{$\mathrm{E}$} & Total no. & 10 & 16 & 26 \\
\hline & $\%$ within Hardy grade & $38.5 \%$ & $61.5 \%$ & $100.0 \%$ \\
\hline & $\%$ within final remission & $23.8 \%$ & $42.1 \%$ & $32.5 \%$ \\
\hline \multirow[t]{3}{*}{ Total } & Total no. & 42 & 38 & 80 \\
\hline & $\%$ within Hardy grade & $52.5 \%$ & $47.5 \%$ & $100.0 \%$ \\
\hline & $\%$ within final remission & $100.0 \%$ & $100.0 \%$ & $100.0 \%$ \\
\hline
\end{tabular}

39 patients, significant tumor was seen during follow-up in 30 patients whereas 9 had insignificant residue.

- Visual: Of the 46 patients with preoperative visual deficits, 19 (41\%) had improvement in visual deficits in follow-up. Visual deterioration was observed in two patients. In one of those patients, preoperative vision was normal whereas in the other, it was worsening of preoperative visual deficit.
Recurrence: Out of 43 patients who achieved remission, only 4 had biochemical recurrence in follow-up (9\%).

Correlation between size of the tumor and remission: In our series, only one patient had microadenoma. Postoperative remission was achieved in that patient, but during follow up at 1 year, he had GH value of $11.5 \mathrm{ng} / \mathrm{mL}$ suggestive of recurrence. He was reoperated and achieved remission. In Hardy grade 0 adenomas, remission rate was

Table 4 Correlation between preoperative GH level and remission

\begin{tabular}{|c|c|c|c|c|}
\hline \multirow{2}{*}{$\begin{array}{l}\text { Preoperative GH level } \\
\text { (ng/mL) }\end{array}$} & \multirow[t]{2}{*}{ No. of patients } & \multicolumn{2}{|c|}{ Final remission } & \multirow[t]{2}{*}{ Total } \\
\hline & & Yes & No & \\
\hline \multirow[t]{3}{*}{$<40$} & Total no. & 27 & 11 & 38 \\
\hline & $\%$ within $\mathrm{GH}$ level & $71.1 \%$ & $28.9 \%$ & $100.0 \%$ \\
\hline & $\%$ within final remission & $64.3 \%$ & $28.9 \%$ & $47.5 \%$ \\
\hline \multirow[t]{3}{*}{$\geq 40$} & Total no. & 15 & 27 & 42 \\
\hline & $\%$ within $\mathrm{GH}$ level & $35.7 \%$ & $64.3 \%$ & $100.0 \%$ \\
\hline & $\%$ within final remission & $35.7 \%$ & $71.1 \%$ & $52.5 \%$ \\
\hline \multirow[t]{3}{*}{ Total } & Total no. & 42 & 38 & 80 \\
\hline & \% within $\mathrm{GH}$ level & $52.5 \%$ & $47.5 \%$ & $100.0 \%$ \\
\hline & $\%$ within final remission & $100.0 \%$ & $100.0 \%$ & $100.0 \%$ \\
\hline
\end{tabular}

Abbreviation: $\mathrm{GH}$, growth hormone. 
Table 5 Size, grade, and invasiveness of the adenoma

\begin{tabular}{|l|l|l|l|l|l|l|}
\hline Study & $\begin{array}{l}\text { Microadenoma } \\
(\%)\end{array}$ & $\begin{array}{l}\text { Macroadenoma } \\
(\%)\end{array}$ & $\begin{array}{l}\text { Intrasellar } \\
\text { adenoma (\%) }\end{array}$ & $\begin{array}{l}\text { Infra/para/suprasellar } \\
\text { adenoma (\%) }\end{array}$ & $\begin{array}{l}\text { Noninvasive } \\
\text { adenoma (\%) }\end{array}$ & $\begin{array}{l}\text { Invasive } \\
\text { adenoma } \\
(\%)\end{array}$ \\
\hline $\begin{array}{l}\text { Ross and } \\
\text { Wilson }\end{array}$ & 14 & 86 & 79 & 21 & 69 & 31 \\
\hline $\begin{array}{l}\text { Minniti } \\
\text { et al1 }\end{array}$ & 17 & 83 & 28 & 62 & - & - \\
\hline $\begin{array}{l}\text { Kruetzer } \\
\text { et al1 }\end{array}$ & 33 & 67 & 46 & 54 & 46 & 54 \\
\hline $\begin{array}{l}\text { Present } \\
\text { study }\end{array}$ & 1 & 99 & 10 & 90 & 47 & 53 \\
\hline
\end{tabular}

$100 \%$. In grades A and B adenomas, it was $57 \%$, whereas in grades C and D adenomas remission rate of $43 \%$ was observed. In grade E adenomas, remission rate was $38 \%$. There was association between these two variables $(p=0.09)$. In 41 patients with invasive adenomas, remission rate was observed in 13 (31\%) patients, whereas 30 patients (76\%) remission in noninvasive adenoma group (-Table 3). Out of 26 patients with cavernous sinus invasion, only 10 (38.5\%) patients achieved remission, whereas out of 54 patients without cavernous sinus invasion, 32 (59.3\%) patients achieved remission. Though there is a correlation between these two groups, it was not statistically significant $(p=0.08)$ (

Correlation between preoperative GH level and remission: For correlation, patient groups were divided into two groups, based on preoperative serum GH value. Those with serum $\mathrm{GH}$ level $<40 \mathrm{ng} / \mathrm{mL}$ had remission rate of $71 \%$ whereas those with serum GH levels $\geq 40 \mathrm{ng} / \mathrm{mL}$ had remission rate of $37 \%$. The difference in these two groups was statistically significant $(p=0.02)$ ( $~-$ Table 4 ).

\section{Discussion}

\section{Demography and Clinical Features}

In our study, males and females were almost equally affected (51 males and 42 females). Seventy-seven percent patients were young ( $<40$ years) with a mean age of $32.71 \pm 10.16$ years. Scacchi et al and Esposito et al observed similar demography in their study. ${ }^{1}$ Forty-nine percent patients presented with visual disturbances, which is higher than in available literature. This could be due to the delayed presentation in our patients. Hypopituitarism was observed in $43 \%$ patients and menstrual irregularities were the most common endocrinologic manifestation in females. About 57\% patients presented with headache. Holdaway and Rajasoorya, ${ }^{2}$ in their study on epidemiology of acromegaly, noticed that the incidence of visual field defect ranged between 4 and $62 \%$ in different series in the literature. The incidence of headache mentioned is between 37 and $87 \%$. Higher incidence of visual disturbances in our study suggests the higher incidence of macroadenomas with significant suprasellar extension. We observed hypopituitarism at presentation in $43 \%$ patients. This finding is almost the same as observed by Esposito et al. ${ }^{1}$ Four patients had pituitary apoplexy at presentation. Occurrence of apoplexy in GH-secreting pituitary adenoma is rare and reported incidence is $2 \%$ of all macroadenomas. 3,4

The prevalence is estimated to be 40 to 130 per million inhabitants and is most often diagnosed in middle-aged adults (average age 40 years). ${ }^{1,2}$ Because of the insidious onset and slow progression, acromegaly is frequently diagnosed from 4 to more than 10 years after its onset. ${ }^{1}$ Acromegaly reduces life expectancy with the death rate among acromegaly patients being more than twice that of a control population. ${ }^{5}$

\section{Diagnosis}

The endocrine criteria include an elevated basal GH level ( $>$ $5 \mathrm{ng} / \mathrm{mL}$ ), insufficient $\mathrm{GH}$ suppressibility ( $>2 \mathrm{ng} / \mathrm{mL}$ ) on OGTT, and elevation of serum IGF-1 levels. ${ }^{5}$ Measurement of circulating GH-releasing hormone (GHRH) is the preferred test for the differential diagnosis between GH-secreting pituitary adenoma and ectopic GHRH secretion.. Esposito

Table 6 Remission rates in different series

\begin{tabular}{|c|c|c|c|c|c|}
\hline \multirow[t]{2}{*}{ Author } & \multirow{2}{*}{$\begin{array}{l}\text { No. of } \\
\text { Patients }\end{array}$} & \multicolumn{3}{|c|}{ Remission rates (\%) } & \multirow[t]{2}{*}{ Remission criteria } \\
\hline & & Total & Microadenoma & Macroadenoma & \\
\hline Ross and Wilson ${ }^{6}$ & 153 & 56 & NA & NA & $\mathrm{GH}<5 \mathrm{ng} / \mathrm{mL}$ \\
\hline Losa et $\mathrm{al}^{7}$ & 29 & 55 & NA & NA & $\mathrm{GH}<1 \mathrm{ng} / \mathrm{mL}$ on OGTT and normal IGF- 1 level \\
\hline Fahlbusch et $\mathrm{al}^{4}$ & 222 & 56 & 72 & 49 & $\mathrm{GH}<2 \mathrm{ng} / \mathrm{mL}$ during OGTT \\
\hline Tindall et $\mathrm{al}^{8}$ & 91 & 82 & NA & NA & $\mathrm{GH}<5 \mathrm{ng} / \mathrm{mL}$ and/or normal IGF-1 level \\
\hline
\end{tabular}

Abbreviations: $\mathrm{GH}$, growth hormone, IGF-1, insulin-like growth factor 1; NA, not applicable; OGTT, oral glucose tolerance testing. 
et $\mathrm{al}^{1}$ observed hypopituitarism in $45 \%$ of patients. The average $\mathrm{GH}$ level in their series was $32.6 \pm 6.1 \mathrm{ng} / \mathrm{mL}$. Ross et $\mathrm{al}^{6}$ noticed that approximately $34 \%$ patients had preoperative $\mathrm{GH}$ level $>50 \mathrm{ng} / \mathrm{mL}$. Six of our patients had increase in serum prolactin level suggestive of common acidophilic origin of both the cell lines.

\section{Correlation between Grade of the Tumor and Remission}

Our study had maximum number (99\%) of macroadenomas with $90 \%$ adenomas having suprasellar or parasellar extension. About 50 (53\%) had invasive adenoma similar to the series reported by Kruetzer et al. ${ }^{7}$ Among the patients with invasive adenoma, 32 (34\%) had adenomas invading the cavernous sinus, thereby making the total extirpation of tumor difficult. This is in contrast to the other studies, which have a higher incidence of microadenomas and a lesser frequency of invasiveness ( $\mathbf{- T a b l e ~} \mathbf{5}$ ).

Tumor size and invasion status have a clear influence on surgical outcome. Understandably, remission rates are highest for microadenomas, and they drop significantly for invasive macroadenomas and those with extrasellar extension. Postoperative remission for all macroadenomas varies from 49 to $77 \%$. When remission rates of diffuse (grade II) and invasive (grades III and IV) macroadenomas are separated, outcomes among the latter are considerably less favorable. For grades II, III, and IV tumors, Tindall and coworkers reported remission rates of $60,23.1$, and $0 \%$, respectively. ${ }^{8}$ The radiotherapeutic response of somatotroph adenomas is predictable. GH levels drop to $50 \%$ of baseline in the first 2 years and to $75 \%$ of baseline after 5 years. The latent interval required to suppress $\mathrm{GH}$ levels to $<5 \mathrm{ng} / \mathrm{mL}$ is at least 10 years. Radiation therapy also effectively halts tumor progression. ${ }^{9}$

In our study, we observed a correlation between Hardy grade and final remission. Patients with Hardy grade 0 had remission in $100 \%$ cases, in grades A and B it was $57 \%$, and in grades $C$ and $D$ adenomas remission rate was $43 \%$. In grade $E$ adenomas, remission rate was $38 \%$. We observed a correlation between cavernous sinus invasion and remission. Only $38.5 \%$ patients with cavernous sinus invasion could achieve remission whereas 59.3\% patients without invasion achieved remission. We observed that higher the grade of the tumor, the lesser is the chance of remission. Similarly, we observed a correlation between invasiveness of the tumor and chances of remission. Invasive adenomas had only $31 \%$ remission whereas noninvasive adenomas had remission in $74 \%$ of cases. Tindall et $\mathrm{al}^{8}$ observed the remission rate of $23 \%$ in invasive adenomas whereas $60 \%$ in noninvasive adenomas. While in patients with cavernous sinus invasion, their remission rate was $0 \%$. Ross and Wilson ${ }^{6}$ observed remission rate of $23 \%$ in stage IV tumors whereas it was $57 \%$ each for stages III and II. Minniti et al ${ }^{10}$ observed the remission rate in microadenomas to be $81 \%$. In invasive adenomas and adenomas with cavernous sinus invasion, remission rate was $38 \%$ and $4 \%$ respectively. Similarly, Esposito et $\mathrm{al}^{1}$ observed biochemical remission in $76 \%$ of microadenomas and $51 \%$ of macroadenomas (- Table 6). ${ }^{11-16}$ Reduced biochemical remission in our series can be attributed to the higher number of invasive adenomas.

\section{Correlation between Preoperative Growth Hormone Level and Remission}

The mean serum GH level was $52.05 \mathrm{ng} / \mathrm{mL}$. About 50\% patients had $\mathrm{GH}$ level $>40 \mathrm{ng} / \mathrm{mL}$.

Ross et $\mathrm{al}^{6}$ observed the serum $\mathrm{GH}$ value of $<50 \mathrm{ng} / \mathrm{mL}$ in $66 \%$ patients. Also, Esposito et al $^{1}$ observed mean $\mathrm{GH}$ value to be $32.6 \pm 6.1 \mathrm{ng} / \mathrm{mL}$ in their series. Minniti et al ${ }^{10}$ observed that only $20 \%$ patients in their series had $\mathrm{GH}$ level $>50 \mathrm{ng} / \mathrm{mL}$. Serum GH levels were higher in our study as compared with other studies, again probably due to delayed presentation in our cohort. Hyperprolactinemia was present in $28 \%$ patients in our series, which is slightly lower compared with literature where it ranges from 37 to $38 \%{ }^{1,10}$

The control of GH- and IGF-1 secretion is the main goal of treatment, as normalization of these two parameters is the most significant determinant of reversing the increased mortality rate of the patients. Because this is a study, which spans a time before the criteria were altered, we have used the older criteria $(<5 \mathrm{ng} / \mathrm{mL}$ ) for defining remission.

In our series, we observed remission in $37 \%$ cases in patients with preoperative serum $\mathrm{GH}$ level $\geq 40 \mathrm{ng} / \mathrm{mL}$ whereas patients with level $<40 \mathrm{ng} / \mathrm{mL}$ had remission in $71 \%$ of the cases. The comparison with various series is detailed in - Tables 5, $\mathbf{6}$.

\section{Complications}

Out of 93 patients, 18 (19\%) had postoperative CSF leak. Four patients required reexploration and sellar floor reconstruction. Eight patients had postoperative meningitis. This is in comparison to Ross et $\mathrm{al}^{7}$ who mentioned postoperative CSF leak in $5 \%$ patients, which required surgical intervention in $2 \%$ cases. In their series $2 \%$ patients had meningitis whereas carotid injury was noted in $1 \%$ patients. Minniti et $\mathrm{al}^{10}$ observed CSF leak in $4 \%$ patients and diabetes insipidus in $8 \%$ patients. They observed meningitis in $1 \%$ patients and none of the patients had visual deterioration. Esposito et $\mathrm{al}^{1}$ observed CSF leak in $3 \%$ patients whereas diabetes insipidus was noticed in 9\% cases. Higher incidence of CSF leak and meningitis in our series could be because of higher number of invasive tumors. Also, CSF leak was a significant $(p<0.05)$ risk factor for infection, and hence all attempts must be made to prevent intraoperative CSF leak.

\section{Conclusion}

In this series, one of the largest in available literature from our country, we have examined our experience with surgical management of $\mathrm{GH}$-secreting pituitary adenomas. In this series, one of the largest of its kind, the main factors influencing unfavorable outcome include macroadenomas, invasiveness, high basal $\mathrm{GH}>45 \mathrm{ng} / \mathrm{mL}$ levels, and mixed adenomas. Though our overall rates of complete remission are slightly lower than available literature, they are comparable with the literature when the cohort characteristics with a 
significantly higher proportion of unfavorable prognostic factors are taken into consideration.

\section{References}

1 Esposito V, Santoro A, Minniti G, et al. Transsphenoidal adenomectomy for GH-, PRL- and ACTH-secreting pituitary tumours: outcome analysis in a series of 125 patients. Neurol Sci 2004;25(05):251-256

2 Holdaway IM, Rajasoorya C. Epidemiology of acromegaly. Pituitary 1999;2(01):29-41

3 John A, Kamal T, Edward R. Pituitary tumors-functioning and Nonfunctioning. In: Richard $\mathrm{WH}$, ed. Youmans Neurological Surgery. 6th ed, Vol 2. Philadelphia, PA: Elsevier Saunders; 2011: chap 34

4 Fahlbusch R, Honegger J, Buchfelder M. Surgical management of acromegaly. Endocrinol Metab Clin North Am 1992;21(03): 669-692

5 Sheaves R, Jenkins P, Blackburn P, et al. Outcome of transsphenoidal surgery for acromegaly using strict criteria for surgical cure. Clin Endocrinol (Oxf) 1996;45(04):407-413

6 Ross DA, Wilson CB. Results of transsphenoidal microsurgery for growth hormone-secreting pituitary adenoma in a series of 214 patients. J Neurosurg 1988;68(06):854-867

7 Losa M, Oeckler R, Schopohl J, Müller OA, Alba-Lopez J, von Werder K. Evaluation of selective transsphenoidal adenomectomy by endocrinological testing and somatomedin- $\mathrm{C}$ measurement in acromegaly. J Neurosurg 1989;70(04):561-567

8 Tindall GT, Oyesiku NM, Watts NB, Clark RV, Christy JH, Adams DA. Transsphenoidal adenomectomy for growth hormonesecreting pituitary adenomas in acromegaly: outcome analysis and determinants of failure. J Neurosurg 1993; 78(02):205-215

9 Eastman RC, Gorden P, Glatstein E, Roth J. Radiation therapy of acromegaly. Endocrinol Metab Clin North Am 1992;21(03): 693-712

10 Laws ER Jr, Thapar K. Recurrent pituitary adenomas. In: Landolt AM, Vance ML, Reilly PL, eds. Pituitary Adenomas. Edinburgh, UK: Churchill Livingstone; 1996:385-94

11 Möller-Goede DL, Brändle M, Landau K, Bernays RL, Schmid C. Pituitary apoplexy: re-evaluation of risk factors for bleeding into pituitary adenomas and impact on outcome. Eur J Endocrinol 2011;164(01):37-43

12 Minniti G, Jaffrain-Rea ML, Esposito V, Santoro A, Tamburrano G, Cantore G. Evolving criteria for post-operative biochemical remission of acromegaly: can we achieve a definitive cure? An audit of surgical results on a large series and a review of the literature. Endocr Relat Cancer 2003;10(04):611-619

13 Kreutzer J, Vance ML, Lopes MB, Laws ER Jr. Surgical management of $\mathrm{GH}$-secreting pituitary adenomas: an outcome study using modern remission criteria. J Clin Endocrinol Metab 2001;86(09):4072-4077

14 Abosch A, Tyrrell JB, Lamborn KR, Hannegan LT, Applebury CB, Wilson $\mathrm{CB}$. Transsphenoidal microsurgery for growth hormonesecreting pituitary adenomas: initial outcome and long-term results. J Clin Endocrinol Metab 1998;83(10):3411-3418

15 Swearingen B, Barker FG II, Katznelson L, et al. Long-term mortality after transsphenoidal surgery and adjunctive therapy for acromegaly. J Clin Endocrinol Metab 1998;83(10):3419-3426

16 Freda PU, Wardlaw SL, Post KD. Long-term endocrinological followup evaluation in 115 patients who underwent transsphenoidal surgery for acromegaly. J Neurosurg 1998;89(03):353-358 